\title{
Phytoremediation of batik industry wastewater using water hyacinth plant as a medium for maintaining Cyprinus Carpio L.
}

Hadi Susilo ${ }^{1,}{ }^{*}$, Swastika Oktavia ${ }^{2}$, Roudatussa' adah ${ }^{3}$

Biology Department, Universitas Mathla'ul Anwar Banten, Banten, Indonesia

${ }^{1}$ hadisusilo1973@gmail.com *; ${ }^{2}$ swastika.oktavia28@gmail.com; ${ }^{3}$ Udohsaah@gmail.com

* Corresponding author

\begin{tabular}{l}
\hline ARTICLE INFO \\
\hline Article history \\
Submission March 14, 2021 \\
Revision March 25, 2021 \\
Accepted April 24, 2021 \\
Keyword \\
Batik liquid waste \\
Phytoremediation \\
Hyacinth plants
\end{tabular}

ABSTRACT

Batik is one of Indonesia's cultural heritage that has been recognized internationally. Currently, public demand for batik continues to increase, increasing the production of the batik industry in Banten and will be the impact of increasing batik liquid waste. The results of batik production waste are usually directly disposed of through public water channels without being treated first. This condition can cause environmental pollution that will disrupt the sustainability of aquatic ecosystems. The purpose of this study was to determine the effect of phytoremediation of batik industrial wastewater on the lethality and structure of Cyprinus Carpio L. scales. This study used a completely randomized design with 5 treatments and 3 repetitions. The treatment used was the maintenance of Cyprinus Carpio L. in the wastewater from the phytoremediation batik industry with concentrations of $0 \%$, $5 \%, 10 \%, 20 \%$, and $40 \%$. The results showed that phytoremediation using water hyacinth plants reduced the BOD and COD content of batik waste. Phytoremediation of batik waste affects the lethality of Cyprinus Carpio L. and the structure of the scales. At concentrations of $20 \%$ and $40 \%$, the highest average percentage of lethality is $60 \%$ death. Fish mortality is characterized by changes in behavior such as movement activity, body balance, and color morphology. The concentration of the batik industry wastewater also affects the amount of lethality and the sublethal effect of Cyprinus Carpio L. The attachment of the waste indicates the sublethal effect to the scales, the highest concentration of which is $20 \%$ and $40 \%$, respectively.

Conflict of interest: The authors declare that they have no conflicts of interest.

\section{Introduction}

Batik is one of Indonesia's cultural heritage that has been recognized internationally. Currently, public demand for batik continues to increase, increasing the production of the batik industry in Banten and will be the impact of increasing batik liquid waste. Most batik industry liquid waste is not treated before being discharged into water bodies because the processing requires expensive costs, and there are many difficulties in processing it ${ }^{1}$. Most batik industries on a household scale do not have an IPAL (Wastewater Treatment Plant) 
system to handle their waste, so they dispose of the waste directly into ditches, eventually empty it into rivers. This situation can interfere with the aesthetics of the waters, block the penetration of sunlight into water bodies, reduce the quality of the environment and damage the life that exists in the environment. Besides that, it can cause itching, heat, dry skin, and hardness ${ }^{2}$. Most batik industry wastewater comes from the dyeing and wax removal process ${ }^{3}$. Batik industry wastewater generally contains surfactants, dyes, pigments, resins, chelating agents, dispersing agents, inorganic salts, heavy metals, biocides and contains many oxygendemanding chemicals (COD) and BOD. The most commonly used dyes in the textile industry are red, golden yellow, and remazol black ${ }^{4}$. BOD (Biological Oxygen Demand) shows the amount of dissolved oxygen needed by living microorganisms to decompose or oxidize waste materials in water. COD (Chemical Oxygen Demand) shows the amount of oxygen in ppm or milligrams per liter required by oxidants to oxidize organic matter in water chemically. These organic materials generally do not undergo rapid biological decomposition as in the five-day BOD test, but these organic compounds also reduce water quality ${ }^{5}$.

Based on the literature, several regulations refer to batik waste, including the Decree of the State Minister of the Environment Number 01 of 2010 regarding water pollution control. The Indonesian government has set quality standards for the types of pollutants in waste, including BOD5 $60 \mathrm{mg} / \mathrm{L}$, COD $150 \mathrm{mg} / \mathrm{L}$, TSS $50 \mathrm{mg} / \mathrm{L}$, Total Phenol $0.5 \mathrm{mg} / \mathrm{L}$, Total Chromium (Cr) $1.0 \mathrm{mg} / \mathrm{L}$, Ammonium Total (NH3-N) $8.0 \mathrm{mg} / \mathrm{L}$, Sulfide (S) $0.3 \mathrm{mg} / \mathrm{L}$, Oils and Fats $3.0 \mathrm{mg} / \mathrm{L}$, and $\mathrm{Ph} 6.0-9.0^{6}$. The absorption of waste by fish will accumulate in the gills and scales. Scales on fish function as an organ of protection from external influences ${ }^{7}$. Damage to fish scales due to pollutants will disrupt the body's defense system and fish osmoregulation $^{8}$.

One way to treat industrial waste is by using phytoremediation techniques. Phytoremediation is a certain plant system that can cooperate with microorganisms in the media (soil, coral, and water), can convert contaminants (pollutants/pollutants) into less or harmless or even economically useful materials. Aquatic plants that can be used for the phytoremediation process are water hyacinth ${ }^{9}$.

\section{Method}

\section{Research place}

The research was carried out from July-October 2020 at the Integrated Laboratory of the Faculty of Science, Pharmacy and Health (FSFK-UNMA) Banten. BOD and COD measurements were carried out at the Serang Banten Environmental Service.

\section{Tools and materials}

The tools used in the research include a jar or bucket, aquarium, aerator, measuring cup, $50 \mathrm{~L}$ plastic container, fish filter, analytical balance, litmus paper, temperature measuring device, label paper, gloves, stationery, ruler, titration tool. Used to measure BOD, COD, glass slides, surgical instruments, and microscopes. The materials used in the study included liquid waste, water hyacinth, carp, and carp feed.

\section{Procedure}

\section{Batik Industry Liquid Waste Sampling}

Samples were taken from the training center and the batik industry in Kubil Village, Serang, Banten. The sample was taken as much as $50 \mathrm{~L}$.

\section{Water Hyacinth Plant Sampling}

Water hyacinth plants were taken directly from the lame sublime river, Pandeglang Regency, Banten, as many as 7 plants were then acclimatized for 7 days.

\section{Goldfish Sampling}

Goldfish samples were taken from the fish farming area of Pandeglang Regency, Banten. The goldfish sample used was still in the preadolescent stage; 75 fish were taken with 
a weight of 3-5 g, measuring 3-5 cm, aged 45-60 days. Before testing, goldfish were first acclimatized for 7 days.

\section{Measurement of BOD and COD}

Measurements of BOD and COD were carried out at the Laboratory of the Environmental Service, Serang, Banten. BOD measurements were carried out for five days with 1 liter of batik liquid waste samples.

\section{Phytoremediation Test}

Phytoremediation testing using water hyacinth was carried out for 12 days.

\section{Testing of Phytoremediation Results for Carp Maintenance}

The results of phytoremediation using water hyacinth plants were used as carp rearing with wastewater concentrations of $0 \%, 5 \%, 10 \%, 20 \%$, and $40 \%$. Cyprinus. Carpio L. carried out maintenance during maintenance for seven days.

\section{Data collection}

\section{Lethality of Goldfish (Cyprinus. Carpio L.)}

The lethality or death of Cyprinus. Carpio L. is characterized by behavior that moves irregularly and jumps to the water's surface; eventually, the fish will weaken and cause death. The lethality or death of Cyprinus. Carpio L. can be calculated based on the formula (1).

$$
P L=\frac{N t \times 100 \%}{N o}
$$

The percentage of lethality is mention using PL, which can be obtained by calculating Nt (Number of dead fish) multiplied 100\%, then divided with No (Number of fish at the beginning of maintenance).

The Sublethal Effects of Cyprinus. Carpio L.

Sublethal or acute effects are obtained from microscopic images of scales that are damaged by exposure to wastewater. The scales were taken using tweezers and placed on a glass slide, then observed using a microscope with a minor magnification of 4 x 10 .

\section{Data analysis}

Analysis of BOD and COD data, environmental parameters, and sublethal effects of carp were analyzed descriptively. Meanwhile, goldfish lethality data were statistically analyzed using the Kruskal Wallis test followed by the Mann Whitney test.

\section{Results and Discussion}

Phytoremediation has a role in reducing the levels of BOD and COD, as shown in Figure 1. The results of the measurement of BOD and COD have decreased. BOD and COD measurements before phytoremediation were BOD levels of $384 \mathrm{mg} / \mathrm{L}$ and COD of 872.5 $\mathrm{mg} / \mathrm{L}$, and these results indicate that they exceed the specified quality standard threshold ${ }^{6}$. This condition shows that the analyzed liquid waste samples can pollute and are harmful to living things and the environment; it is necessary to do a processing system to reduce pollutants in batik waste.

The results of the phytoremediation test showed that the BOD and COD values decreased. The test results obtained BOD levels of $307 \mathrm{mg} / \mathrm{L}$ and COD of $353 \mathrm{mg} / \mathrm{L}$. This result shows that phytoremediation with water hyacinth plants has a real impact on reducing batik waste pollutants; this has similarities with research conducted in $2016^{9}$. Water hyacinth is an aquatic plant that can stabilize the aquatic environment that is polluted by various pollutants. Water hyacinth plants can remove pollutants because of their function as a biological filtration system. They can absorb organic, inorganic, and pollutant substances because water hyacinths can form phytochelatins that produce peptide compounds that can attract large amounts of pollutants ${ }^{10}$. 


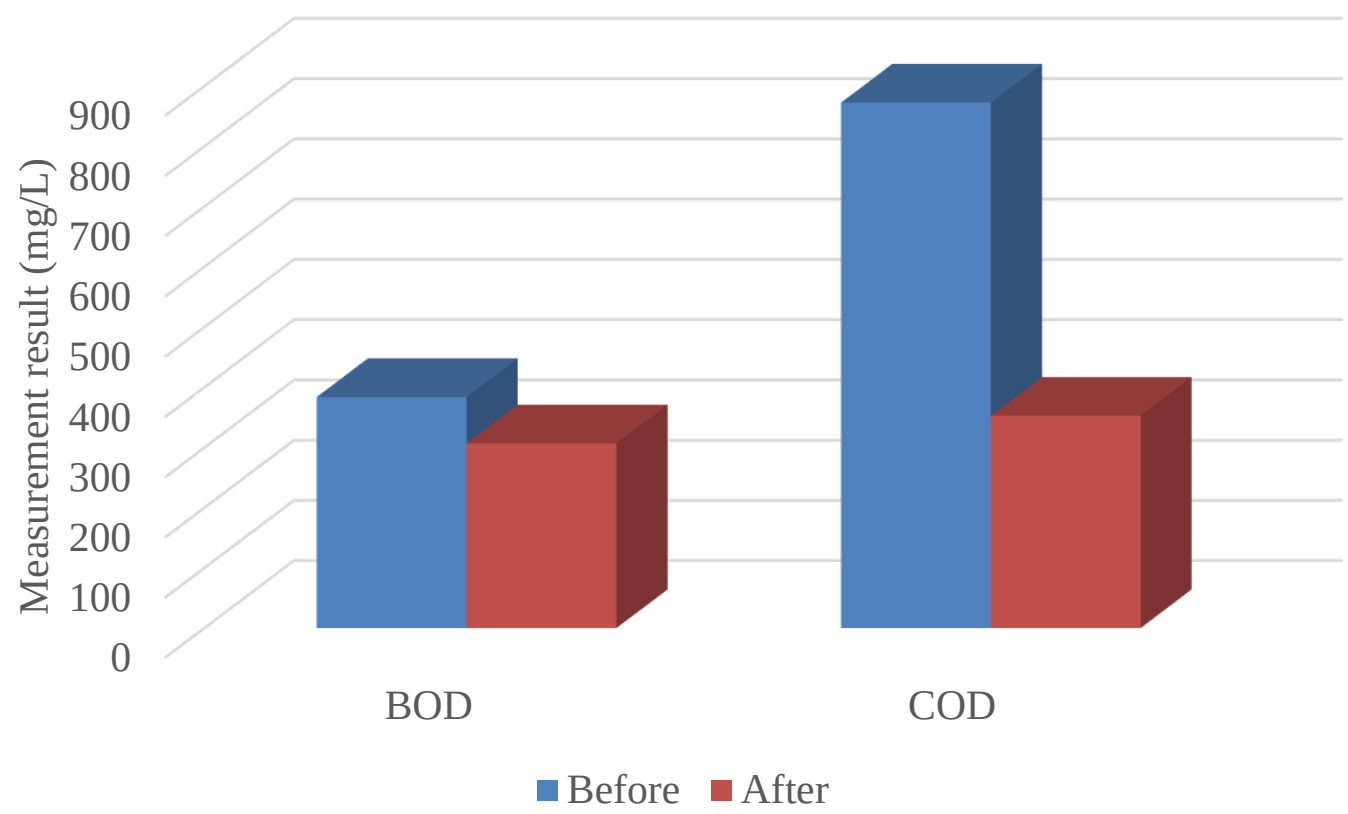

Fig 1. impact phytoremediation water hyacinth plants to on levels of BOD and COD in batik liquid waste

\section{Lethality Observation of Goldfish (Cyprinus Carpio L.)}

The study results showed that the effect of phytoremediation batik waste had a significant effect on the survival of goldfish. The data analysis of the Kruskal Wallis Test showed that the statistical data on the percentage of lethality was 0.005 , meaning that it was significantly different; this indicates that wastewater affects the lethality of carp.

The Mann-Whitney test data analysis results showed that the average value $<0.05$ means that it is significantly different, and the average value is $>0.05$, which means that it is no different. The Mann-Whitney test shows no difference between the concentrations of $5 \%$ and $10 \%$, which is almost the same, and this shows that at the $5 \%$ level, it can cause lethality in carp.

Research conducted by Nuha in 2016 the value of LC50-96 hours of liquid waste from Troso weaving on carp affects carp mortality ${ }^{11}$. Fish mortality is characterized by changes in behavior such as changes in movement activity, body balance, ramjet ventilation, mucus production, changes in morphological color.

\section{Data Analysis of Lethality Percentage of Cyprinus Carpio L.}

Table 1. Kruskal-Wallis Test Lethality Percentage of Cyprinus Carpio L.

\section{Lethality percentage}

\begin{tabular}{lc}
\hline Chi-Square & 15.086 \\
Df & 4 \\
Asymp. Sig. & 0.005 \\
\hline
\end{tabular}

Based on table 1, the value of Asymp. Sig less than 0.05 mean the treatment given had a significant difference in the lethality of Cyprinus Carpio L. Furthermore, the Mann-Whitney test was carried out to determine the difference in each treatment (Table 2). Based on Table 2, the sign $(*)$ indicates that the treatment given is different from other treatments, the $0 \%$ treatment shows significantly different results than other treatments. 
Table 2. Lethality Cyprinus Carpio L. using Mann-Whitney

\begin{tabular}{cccccc}
\hline Treatment & $\mathbf{0 \%}$ & $\mathbf{5 \%}$ & $\mathbf{1 0 \%}$ & $\mathbf{2 0 \%}$ & $\mathbf{4 0 \%}$ \\
\hline $0 \%$ & - & $0.01^{*}$ & $0.01^{*}$ & $0.01^{*}$ & $0.01^{*}$ \\
$5 \%$ & $0.01^{*}$ & - & 0.15 & $0.03^{*}$ & $0.03^{*}$ \\
$10 \%$ & $0.01^{*}$ & 0.15 & - & 0.09 & 0.09 \\
$20 \%$ & $0.01^{*}$ & $0.03^{*}$ & 0.09 & - & 1.00 \\
$40 \%$ & $0.01^{*}$ & $0.03^{*}$ & 0.09 & 1.00 & - \\
\hline
\end{tabular}

\section{Observation of Sublethal Effects of Carp (C. Carpio L.)}

Table 3 shows the sublethal effect of carp exposed to batik waste experiences attachment of foreign substances characterized by waste attached to the scales, body condition that is bulging and slightly pale, in contrast, to control carp that looks lighter. Net, but this did not affect the weight of the carp (Table 4).

Table 3. Observation of Sublethal Effects of Carp (C. carpio L.)

\begin{tabular}{|c|c|c|c|c|c|c|}
\hline & $\begin{array}{l}\text { Movement } \\
\text { activity }\end{array}$ & $\begin{array}{c}\text { Body } \\
\text { color and } \\
\text { condition }\end{array}$ & Scale & $\begin{array}{c}\text { Body } \\
\text { bleeding }\end{array}$ & $\begin{array}{c}\text { Fish } \\
\text { balance }\end{array}$ & $\begin{array}{c}\text { Microscopic of scales } \\
(4 \times 10)\end{array}$ \\
\hline $0 \%$ & $\begin{array}{l}\text { Regular/nor } \\
\text { mal }\end{array}$ & Bright & $\begin{array}{l}\text { Scale } \\
\text { clean }\end{array}$ & Not occur & Balance & \\
\hline $5 \%$ & $\begin{array}{l}\text { Tend to up/ } \\
\text { approaching } \\
\text { aerator }\end{array}$ & $\begin{array}{l}\text { Bloated, } \\
\text { pale, there } \\
\text { is waste } \\
\text { sticking }\end{array}$ & $\begin{array}{l}\text { Loose } \\
\text { scales }\end{array}$ & Not occur & Balance & \\
\hline $10 \%$ & $\begin{array}{l}\text { Tend to up/ } \\
\text { approaching } \\
\text { aerator }\end{array}$ & $\begin{array}{l}\text { Bloated, } \\
\text { pale, there } \\
\text { is waste } \\
\text { sticking }\end{array}$ & $\begin{array}{l}\text { Loose } \\
\text { scales }\end{array}$ & Not occur & Balance & \\
\hline $20 \%$ & $\begin{array}{l}\text { Tend to up/ } \\
\text { approaching } \\
\text { aerator }\end{array}$ & $\begin{array}{l}\text { Bloated, } \\
\text { pale, a lot } \\
\text { of waste } \\
\text { stuck }\end{array}$ & $\begin{array}{l}\text { Loose } \\
\text { scale }\end{array}$ & Occur & $\begin{array}{l}\text { Not } \\
\text { balance }\end{array}$ & \\
\hline $40 \%$ & $\begin{array}{l}\text { Tend to up/ } \\
\text { approaching } \\
\text { aerator }\end{array}$ & $\begin{array}{l}\text { Bloated, } \\
\text { pale, a lot } \\
\text { of waste } \\
\text { stuck }\end{array}$ & $\begin{array}{l}\text { Many } \\
\text { scale are } \\
\text { missing }\end{array}$ & Occur & $\begin{array}{l}\text { Not } \\
\text { balance }\end{array}$ & \\
\hline
\end{tabular}

The increase in fish weight is thought to be because the fish feed consumed is easily digested and contains good protein for fish growth. Handajani and Widodo stated that growth increases volume and weight in a particular time ${ }^{12}$. Many factors affect the growth of fish. The external factors affecting fish growth include water temperature, dissolved oxygen 
content, ammonia, salinity, irradiation, and duration of irradiation. The research results conducted by Jusmaldi and Hariani show that the relationship between length and weight and condition factors of two-spotted wader fish in the Barambai river polluted by coal mining is in good condition characterized by a positive allometric growth pattern ${ }^{13}$. The attachment of the waste to the scales is different for each given treatment. The higher the concentration of given waste, the more waste that sticks.

The scales owned by carp seeds function as a protector to prevent the content of wastewater into the body. Almost all goldfish fry at a concentration of $5 \%-40 \%$ in the study showed foreign substances attached to their scales from batik liquid waste. In the first treatment $(0 \%)$, the morphology of the scales looked clean, and there was no waste sticking. The second treatment (5\%) and the third treatment (10\%) showed almost the same results, and there was waste attached to the scales. The fourth treatment with a concentration of $20 \%$ showed quite a lot of waste sticking, while in the fifth treatment, the highest concentration of $40 \%$, there was much waste that filled the cross-section of carp scales. Damage to goldfish scales can only be seen from the color of goldfish scales.

Following Andriani and Hartini's research, the gift of tilapia seeds showed foreign substances attached to the scales exposed to batik waste ${ }^{14}$. Before the occurrence of lethality or death, goldfish experience changes in behavior. Changes in behavior that occur are loss of balance, the tendency of fish to gather on the water's surface, difficulty breathing, and the color of the fish fades ${ }^{15}$.

Table 4. Weight of C. Carpio L. by the treatment

\begin{tabular}{cccc}
\hline \multirow{2}{*}{ Treatment } & \multicolumn{2}{c}{ Weight of C. Carpio L (g) } & \multirow{2}{*}{ Average } \\
\cline { 2 - 3 } & Before treatment & After treatment & \\
\hline $0 \%$ & 3.29 & 3.52 & 3.9 \\
$5 \%$ & 3.23 & 3.30 & 3.8 \\
$10 \%$ & 3.26 & 3.12 & 3.8 \\
$20 \%$ & 3.21 & 3.29 & 3.8 \\
$40 \%$ & 3.10 & 3.26 & 3.7 \\
\hline
\end{tabular}

The picture of carp scales exposed to batik waste is dark because the pigment cells in the carp's body are damaged. In dead fish, the fish will secrete mucus on the branchia and the surface of the fish's body. This mucus secretion is thought to be caused by the presence of waste dye in contact with the fish body. Pigment cells (chromatophores) in the dermis can change to adapt to the environment. The dyes in the liquid waste combine unsaturated organic compounds, chromosomes, and auxoforms, as activators of chromophore work and binders between color and fiber ${ }^{16,17}$. The absorption of dye by melanophores is the cause of goldfish exposure to dark (black) liquid waste.

\section{Conclusion}

The concentration of wastewater produced by phytoremediation affects the lethality of carp. The concentration of wastewater at a concentration of 5\% through phytoremediation using water hyacinth still causes lethality. The concentration of wastewater from phytoremediation affects the microscopic picture of the structure of carp scales where foreign substances are attached to the scales and the dark color of the fish body.

The suggestions necessary for further research that if applied in the batik industry, there is a need for further waste treatment before being discharged into the surrounding environment because batik industry wastes with a concentration of $5 \%$ through phytoremediation water hyacinth still cause lethality. Parameters that need to be added are light intensity and turbidity. 


\section{References}

1. $\quad$ Sari, M. Pengendalian Limbah Cair di Pabrik Benang Karet. (2009).

2. Rossiana, N. Uji toksisitas limbah cair penyamakan kulit terhadap reproduksi dan pertumbuhan Daphnia carinata King-Toxicity test of tannery liquid waste disposal to reproduction daphnia carinata king. (2007).

3. Tangahu, B. V. \& Putri, A. P. The degradation of Bod and Cod of batik industry wastewater using Egeria Densa and Salvinia Molesta. J. Sains \&Teknologi Lingkung. 9, 82-91 (2017).

4. Sirait, M. Cleaner production options for reducing industrial waste: the case of batik industry in Malang, East Java-Indonesia. IOP Conf. Ser. Earth Environ. Sci. 106, 1-5 (2018).

5. Kristanto, P. Ekologi industri. (Penerbit Andi, 2002).

6. Kementerian Lingkungan Hidup. Peraturan menteri negara lingkungan hidup no 01 tahun 2010 tentang tata laksana pengendalian pencemaran air. (Kementerian Lingkungan Hidup, 2010).

7. Soegianto, A., Primarastri, N. A. \& Winarni, D. Pengaruh pemberian kadmium terhadap tingkat kelangsungan hldup dan kerusakan struktur insang dan hepatopankreas pada udang regang. Berk. Penelit. Hayati 10, (2004).

8. Kimball \& W, J. Biologi. (Erlangga, 1991).

9. Suharto, B. dkk. Pengolahan limbah batik tulis dengan fitoremediasi menggunakan tanaman eceng gondok ( Eichornia Crassipes ). J. Sumberd. Alam dan Lingkung. 3, 14 19 (2016).

10. Djo, Y. H. W., Suastuti, D. A., Suprihatin, I. E. \& Sulihingtyas, W. D. Fitoremediasi menggunakan tanaman eceng gondok (Echhornia crassipes) untuk menurunkan COD dan kandungan $\mathrm{Cu}$ dan $\mathrm{Cr}$ limbah cair laboratorium analitik Universitas Udayana. Cakra Kim. 5, 137-144 (2017).

11. Nuha, U. A., Martin, F. P. \& Mubarok, I. Toksisitas letal akut limbah cair tenun troso terhadap ikan mas (Cyprinus carpio L). Life Sci. 5, 1-8 (2016).

12. Handajani, H. \& Widodo, W. Nutrisi Ikan. (UMM Press Malang, 2010).

13. Jusmaldi, . \& Hariani, N. Hubungan panjang bobot dan faktor kondisi ikan wader bintik dua Barbodes binotatus (Valenciennes, 1842) di Sungai Barambai Samarinda Kalimantan. J. Iktiologi Indones. 18, 87-101 (2018).

14. Andriani, R. \& Hartini, H. Toksisitas limbah cair industri batik terhadap morfologi sisik ikan nila gift (Oreochomis nilotocus). J. SainHealth 1, 83-91 (2017).

15. Pratiwi, H. C. Pengaruh toksisitas akut air lindi terhadap ikan mas (Cyprinus carpio). 
(Universitas Airlangga, 2014).

16. Pratiwi, Y. Penentuan tingkat pencemaran limbah industri tekstil berdasarkan nutrition value coeficient bioindikator. J. Teknol. 3, 129-137 (2010).

17. Pratiwi, D. E. Efektivitas instalasi pengolahan air limbah dalam penurunan kadar chemical oxygen demand (COD) di instalasi pengolahan air limbah Mojosongo kota Surakarta. (Universitas Diponegoro, 2010).

\section{Author contributions}

All authors contributed to the study's conception and design. Material preparation, data collection and analysis were performed by [Hadi Susilo], [Swastika Oktavia], and [Roudatussa'adah]. The first draft of the manuscript was written by [Roudatussa'adah] and all authors commented on previous versions of the manuscript. All authors read and approved the final manuscript. 